\title{
CZYSTOŚĆ LORDA SINGELWORTH
}

Bohaterem Tajemnicy Lorda Singelworth jest Anglik, który w Wenecji oddaje się pasji latania balonem. Nie rozumieją go mieszkańcy miasta, on sam chce uchodzić za poważnego myśliciela, a narrator zdaje się z niego kpić. Nowelę interpretowano wnikliwie ${ }^{1}$, ostatnio zaś próbowano analizować relację czystość/nieczystość, która zdaje się obsesją głównego bohatera². Ta kwestia zaintrygowała również mnie ${ }^{3}$, jednak z nieco innej perspektywy. Przesłanie utworu w znacznym stopniu badacze już odsłonili. Kompletna, zamknięta egzegeza, oczywiście i na szczęście, nie jest możliwa, jednak wydaje mi się, że katalog odczytań warto dopełnić wyjaśnieniem, dlaczego bohaterem noweli jest Anglik. Wizerunek tej postaci wydaje się nakreślony zgodnie $\mathrm{z}$ wyobrażeniami pochodzącymi z XIX-wiecznej imagologii ${ }^{4}$. Prześledzenie otwartych w ten sposób wątków treścio-

${ }^{1}$ M. AdAmiEc, Tajemnica lorda Singelworth albo metafizyka balonu, „Studia Norwidiana” 3-4: 1985-1986, s. 201-215, E. DĄBRowicz, , Tajemnica lorda Singelworth” Cypriana Norwida - strategia publicznego mówienia, „Studia Norwidiana” 3-4: 1985-1986, s. 221-223, K. TRYBuś, Maska lorda Singelwortha, „Studia Norwidiana” 14: 1996, s. 96-97, M. GRABOwsKI, Topografia pamięci w ,, Tajemnicy Lorda Singelworth” Norwida, „Pamiętnik Literacki” 2016, z. 4, s. 79-95, Z. DambeK-Giallelis, Tajemnice , Tajemnicy Lorda Singelworth”, „Studia Norwidiana” 35: 2017, s. 185-198.

2 E. KĄCKa, Świat wzniostych uczuć i dobrych manier, czyli Norwidowskie prawo inwersji, „Studia Norwidiana” 38: 2020, s. 99-109.

3 Dodam, że pierwsza wersja niniejszego tekstu powstała przed opublikowaniem w zeszłorocznych „Studiach Norwidianach” ciekawego, erudycyjnego tekstu Elizy Kąckiej.

${ }^{4}$ Joep Leersseen zaprezentował zarówno rys dziejów imagologii jako ,rzeczowego inwentarza obcych bohaterów i opisów obcokrajowców w istniejącym korpusie literackim”, które jednak „stanowiły przedmiot naiwnego esencjalizmu”, a także przedstawił jako interesującą metodę badawczą. J. LEERSSEEN, Imagologia: o zastosowaniu etniczności do nadawania światu sensu, „Porównania. Czasopismo poświęcone zagadnieniom komparatystyki literackiej” 2017, t. 21, nr 2, s. 9-29. 
wych pozwala odpowiedzieć, czemu problem czystości Norwid powiązał z ruchami religijnymi, a także z jakiego powodu Singelworth uprawiał aeronautykę i dlaczego plotki na temat przyczyn latania ogniskowały się wokół kłopotów gastrycznych. Celem mojej analizy nie jest jednak wyłącznie wykazanie, że sylwetka Anglika zbudowana została z narodowych stereotypów. Ta postać wydaje się bowiem dobrze osadzona w świecie przedstawionym, w Wenecji czasu ,przed przełomem”. To wszystko, wraz z faktem, że Tajemnica jest jednym z ostatnich tekstów mądrego wiekiem i literackim doświadczeniem twórcy, skłoniło mnie do uznania, iż Anglik może być rodzajem autoportretu Norwida. Autoportretu częściowego, dla którego - jak sądzę - pendant stanowi wizerunek Toniego di Bona Grazia. O tym drugim powiedziano dotąd więcej, skoncentruję się więc na uzupełnieniu obrazubrytyjskiego lorda.

\section{BALON I KŁOPOTY GASTRYCZNE}

Zasadniczy dla akcji noweli wątek - podróż balonem, przedstawił narrator jako zjawisko powszechnie znane, tłumacząc, że aeronaucja „kilkadziesiąt lat temu nie była upowszechnioną tak rzeczą, jak ona dziś komu wydawać się może" (DW VII, 220). W tekście nie podano wprawdzie informacji o czasie akcji, jednak Austriacy okupowali Wenecję do 1866 roku. Natomiast pierwszy lot balonem w tym mieście odbył się niedługo po paryskim, inicjalnym wzbiciu się w powietrze - w kwietniu $1784^{5}$; aktywność ta nie była jednak kontynuowana przez Włochów, być może dlatego, że to nie oni przewodzili w wyścigu o panowanie w przestworzach. Istnieją listy aeronautów czynnych między 1783 a 1850 rokiem, z których wynika, że długo na niebie dominowali Francuzi, którzy pod koniec tego okresu oddali pierwszeństwo Anglikom. Jak obliczono, w tym czasie wśród 500 pilotów balonów, 313 pochodziło z Wysp ${ }^{6}$. Zapisana w dokumentach z epoki, powszechnie znana, więc nieobca zapewne także Norwidowi, informacja o przeważającej liczbie Wyspiarzy wśród aeronautów może wyjaśniać, dlaczego bohaterem weneckiej przygody jest jeden z nich.

Narodowość tytułowego bohatera tłumaczy obecność jeszcze jednego kontekstu kulturowego w noweli. Balon był tylko jednym z obiektów, choć niewątpliwie na przełomie XVIII/XIX wieku głównym, nowej dziedziny nauki - aeronautyki, to dostarczał również rozrywki, a rozpowszechnienie się baloniarstwa - ak-

5 Lynn M. R., The Sublime Invention: Ballooning in Europe, London 2010, s. 16.

6 Dodam, że na listach znalazły się 104 nazwiska francuskie. Rozwój baloniarstwa był szybki, skoro do 1820 roku liczba wszystkich aeronautów nie przekraczała 200 . W tamtym czasie najwięcej było Francuzów, 12 Włochów, 10 Austriaków, 11 osób z krajów niemieckojęzycznych, 4 Rosjan i 3 Polaków. Tamże, s. 62. 
tywności elitarnej, jednak obserwowanej chętnie i tłumnie, zostawiło ślad w kulturze. Narrator Tajemnicy, streszczając pogłoski dotyczące przyczyn pasji latania Anglika, wymienia, poza najważniejszymi ówczesnymi zastosowaniami balonów ${ }^{7}$, także szyderczą obmowę. Chętnie podchwyconą przez plotkarzy złośliwość francuskiego dziennikarza, jakoby Singelworth znalazł sobie oryginalny sposób na kłopoty gastryczne, podtrzymuje meldunek rosyjskich obserwatorów wojskowych potwierdzający posiadanie przez aeronautę naczynia podobnego do „etruskiej okrągłej wazy, albo porcelanowej” (DW VII, 221), jednocześnie unieważniając podejrzenie militarnego celu lotów. „Profesor w Heidelbergu” podał natomiast powód naukowy: badanie ciśnienia atmosferycznego nad miastami. Ta opinia nie wyeliminowała jednak z obiegu publicznego pogłoski o bardziej przyziemnych powodach balonowej pasji Singelwortha.

Z jakiego powodu nieprzyjemna plotka jest tak żywotna? I dlaczego taki problem znalazł się w noweli? Charakterystycznie dla tekstów Norwida, prawdopodobne wyjaśnienie tego wątku możemy znaleźć w XIX wieku kulturze popularnej. Może się to wydawać dziwne, jednak procesy trawienne i problemy gastryczne interesowały wówczas nie tylko lekarzy. Już pod koniec XVIII wieku badaniami żywieniowych potrzeb człowieka zajęli się chemicy, między innymi Justus von Liebig, który w latach 40. ogłosił powszechną dziś wiedzę na temat wartości odżywczych potraw.

Nieco wcześniej, bo przed połową XVIII wieku pojawiły się teksty naukowe, w których uznawano melancholię, spleen, rozstrój nerwowy, depresję za przypadłości szczególnie często dotykające mieszkańców Wysp Brytyjskich. Wymownym przykładem jest rozprawa The English Malady or a Treatise of Nervous Diseases of all Kinds as Spleen, Vapours, Lowness of Spirits, Hypochondrical, and Hysterical Distempers, etc. George'a Cheyne'a wydana w 1734 roku, którą rozpoczyna wyjaśnienie tytułowego wyliczenia:

Tytuł, jaki wybrałem dla tej rozprawy jest wyrzutem powszechnie czynionym tej Wyspie przez obcokrajowców i wszystkich sąsiadów na kontynencie, którzy nerwowy rozstrój, spleen, wapory i obniżenie ducha nazywają, z drwiną, angielską przypadłością ${ }^{8}$.

7 O naukowych zastosowaniach balonów, zwłaszcza o posługiwaniu się nimi w badaniach meteorologicznych (i rozwoju owych badań dzięki temu): R. GILLESPIE, Ballooning in France and Britain, 1783-1786: Aerostation and Adventurism, „Isis”, 2: 1984 (75), s. 249-268. JSTOR, www.jstor. org/stable/231824, dostęp 12.05.2020, s. 253-254, J. TuCKER, Voyages of Discovery on Oceans of Air: Scientific Observation and the Image of Science in an Age of 'Balloonacy', „Osiris” 11: 1996, s. 144-176. JSTOR, www.jstor.org/stable/301930, dostęp 15.08.2020.

8 G. Cheyne, The English Malady or a Treatise of Nervous Diseases of all Kinds as Spleen, Vapours, Lowness of Spirits, Hypochondrical, and Hysterical Distempers, etc., London 1734, s. i-ii. Tłumaczenie własne - D.P. 
Do źródeł wymienionych kłopotów psychicznych swoich rodaków autor zaliczył między innymi „bujność i żyzność naszej gleby i ciężkość naszego jedzenia”, a także „nastawienie, z jakim się żyje w wielkich, zaludnionych i w konsekwencji niezdrowych miastach"'. Wskazane przez Cheyne'a przyczyny problemów mentalnych: życie w mieście i spowodowaną niezdrowym jedzeniem niestrawność, odnaleźć można w noweli. Jeden z bohaterów Tajemnicy, podobnie pragmatycznie jak Cheyne, zwrócił uwagę na te same źródła trudności z trawieniem (wprawdzie bardziej ogólnikowo niż on), tłumacząc powody codziennego wzbijania się przez Singelwortha w powietrze:

- Wyznać wszakże należy - mówił $\mathrm{D}^{* * *}$ - że są na globie miejsca tak bardzo niezdrowe z różnych powodów, iż owdzie nie byłoby wcale dziwactwem uregulować co dnia siłę trawienia w warunkach swobodniejszych, powracając przeto i silniejszym, i zdrowszym. (DW VII, 226)

Uznanie ciężkostrawnego jedzenia za powód psychicznych udręk może zdumiewać, jednak Cheyne nie był jedynym naukowcem, który wówczas uważał ten związek za oczywisty. Większość, oczywiście, wskazywała na prostszą do zaobserwowania relację przyczynowo-skutkową między głodem a gniewem, aczkolwiek autor The English Malady pisał w cytowanym wyżej wstępie o bogatych, opływających w dostatki Anglikach. Podobne spostrzeżenia zapisał Sydney Whiting w Memoirs of a Stomach, Written by Himself, that Al. Lwio Eat May Read (1853) - powieści groteskowej, choć opartej na najbardziej aktualnych wówczas ustaleniach, udającej uczony lekarski traktat o wnętrznościach i kłopotach trawiennych, w którym żołądek jest siedzibą szlachetnych uczuć (w przeciwieństwie do serca), jego stan decyduje o dyspozycji mózgu, a angielska kuchnia stanowi negatywny przykład odżywiania. Tekst Whitinga był rodzajem literackiego podsumowania mnożących się od końca XVIII wieku tekstów naukowych na temat wpływu kłopotów żołądkowych na inne narządy i zdrowie psychiczne. Na początku XIX stulecia zaczęto też analizować zdrowie przedstawicieli różnych narodów i łączyć najczęstsze statystycznie przypadłości z miejscem zamieszkania i regionalnymi tradycjami (i możliwościami) żywieniowymi. Począwszy więc od takich prac, jak Johna Abernethy'ego The Surgical Works (1815), gdzie przedstawiono stan wiedzy na temat chorób wiązanych z niedyspozycjami żołądkowymi we Francji, w krajach niemieckojęzycznych (w których takie badania pojawiły się wcześniej) i Anglii, zaczęło się też analizowanie stanu brytyjskich żołądków. W efekcie w latach 30. XIX wieku problemy gastryczne uznano za narodową przypadłość Anglików. Rozpowszechnienie się takiego przekonania było nie tylko wynikiem statystycznej obserwacji, lecz także kolej-

9 Tamże. 
nych artykułów naukowych. W wielu z nich pisano o nagminności tej przypadłości, tak było na przykład w Williama Beaumonta Experiments and Observations of the Gastric Juice and the Physiology of Digestionz 1838 roku, czasem, jak w tekście zamieszczonym w Dublin Journal of Medical Science z tego samego roku, pojawiało się sformułowanie, którym wcześniej określano melancholię i tym podobne stany: „narodowa choroba Brytanii” (the national malady of Britain ${ }^{10}$ ). Tak więc nie tylko melancholia była chorobą Anglików, lecz także przyczynowo wiązane z nią kłopoty gastryczne. Istotny dla analizy Tajemnicy jest fakt, że przekonanie to należało do żelaznego repertuaru wyobrażeń imagologicznych i dlatego taka identyfikacja była oczywista dla współczesnego Norwidowi czytelnika. W żadnym ze wskazanych wyżej tekstów nie znalazłem wprawdzie nawet wzmianki o łagodzącym wpływie aeronautyki na dyspepsję, jednak prawdopodobnie takie się pojawiały, skoro jeden z bohaterów - lekarz - podpowiada taką możliwość:

- Wielce przepraszam, że zaprzeczę! - odpowiedział kawaler di San Luca, wzięty wenecki doktor. - Lord, chociażby nawet rzeczywiście miał jedynie na celu uregulowanie żołądka swojego przez heroiczną a periodyczną zmianę atmosfery, nie zasługiwałby bynajmniej na pośmiech u pokornie i nieco głębiej zastanawiających się nad człowiekiem!... (DW VII, 225-226)

Podobną opinię wyraził przywołany wyżej inny bohater noweli - D***, ukryty pod inicjałem z powodu swojej pozycji społecznej (,, wielkie weneckie nazwi$s k o$ "). Singelworth, nieco groteskowy ekscentryk, którego podejrzewano o zajmowanie się głównie szukaniem ulgi dla niewydolnych trzewi, uprawiający niezrozumiałe moralizatorstwo, bywa traktowany przez innych bohaterów poważnie. Powierzenie Anglikowi głównej roli w tekście, jego cechy i stosunek do miasta „zatrzymanego w czasie”, złożonego z pamiątek historycznej chwały i brudu prowokuje do zestawienia go z autorem Tajemnicy.

\section{ANGIELSKA MORALNOŚĆ WEDŁUG NORWIDA}

Niechęć Singewortha do nieczystości miasta jest metaforą jego przekonań moralnych.Tego typu zagadnienia - jak wiadomo - nurtowały Norwida najczęściej. Przyjrzyjmy się zatem jego wyobrażeniu i ocenie tego, co uważał za brytyjską moralność.

Poeta przebywał w Wielkiej Brytanii dwukrotnie. Najpierw, w oczekiwaniu na transport do Stanów Zjednoczonych, spędził kilka dni w Londynie. Dotarł do mia-

10 I. Miller, A Modern history of a Stomach, New York 2016, s. 19. 
sta 3 grudnia, opuścił je 13. Zdążył w tym czasie zwiedzić jedynie Pałac Kryształowy ${ }^{11}$. Trafił tu raz jeszcze, po powrocie ze Stanów Zjednoczonych, pod koniec czerwca 1854 roku, jednak tym razem na nieco dłużej. Został w mieście niemal do końca grudnia, kiedy wyjechał do Paryża (PWsz XI, 185). Pół roku życia w stolicy Wielkiej Brytanii wystarczyło, by stała się ona dla polskiego poety figurą nowoczesności, w każdym razie takiej, jak ją postrzegał. Krytyczną opinię wyraził w wierszu Larwa, zaczynającym się od przywołania ,śliskiego bruku w Londynie”. Przypomnę sytuację liryczną. Mijany we mgle człowiek jawi się podmiotowi mówiącemu jako duch, a zaburzone postrzeganie sprawia, że wydaje się on jednocześnie mieć przeciwstawne cechy: chrystusowe i szalonego obrazoburcy. Dzięki temu, w charakterystyczny dla Norwida sposób, postać mogła zostać porównana do „Biblii księgi / zataczającej się w błocie” (PWsz II, 30). Tematem utworu jest niemoralność sytemu ekonomicznego i społecznego, której skutkiem jest „rozpacz”, ponieważ zasady reguluje - ,pieniądz” (PWsz II, 31). Tak jasna opinia prowokuje do sprawdzenia, czy niewpłynęła ona na wyobrażenie bohatera Tajemnicy. Poetycko nakreślony kilkoma słowami i skojarzeniami przechodzień jest postacią ponurą, choć przez chwilę robi wrażenie ofiary podobnej do Chrystusa („Czoło ma w cierniu?”). Podmiot mówiący nie obarcza go winą, lecz raczej współczuje, tym bardziej, że ma przed sobą szaleńca.

Próżno jednak szukać bezpośrednich podobieństw miedzy postacią z wiersza a Singelworthem. Ten drugi nie jest szaleńcem, raczej dziwakiem czy oryginałem. Można by wprawdzie próbować postrzegać unoszenie się balonem i motywowaną moralnie niechęć do brudu jak tropy popularnej w XIX wiecznej kulturze figury Jezusa ${ }^{12}$, jednak trudno byłoby obronić taką interpretację wobec narratorskiego, ironicznego dystansu do tej postaci. Poszukując takich skojarzeń można by też uznać tandem lord Singelworth - komentator wydarzeń Bona Grazia za XIX-wieczny wariant „Jezusa nowych czasów” i jego proroka. Na pierwszy rzut oka wsparciem dla takiej spekulacji mogłoby być angielskie znaczenie słowa „Lord” - Pan (Bóg) i włoskie Bona Grazia - Dobra Łaska, jednak zasadność podążania tym tropem podważa dokładniejsze przyjrzenie się nazwiskom. „Buonagrazia" oznacza też bowiem dobre maniery ${ }^{13}$. Takiego odczytania nie broniłoby

11 Z. Trojanowiczowa, Z. DAmbeK przy współudziale J. CzARnomorskiej, Kalendarz życia i twórczości Cypriana Norwida, t. I: 1821-1860, Poznań 2007, s. 534.

12 Między innymi o takich przetworzeniach pisałem w książce Przywłaszczenie $i$ strata. Romantyczne transfiguracje Jezusa, Toruń 2014.

13 Rozważania na temat znaczenia nazwiska Toniego zawdzięczam Oldze Płaszczewskiej, za co jej dziękuję. 
również znaczenie nazwiska Anglika: nie tyle wskazuje ono na „worth” - „wartość”, ile podkreśla jej zredukowanie do „single” - „pojedynczości”.

Uczynienie głównym bohaterem Brytyjczyka wnosi znaczenia nacechowane negatywnie. Swoistym komentarzem do Tajemnicy, ze względu na angielskie pochodzenie bohatera i jego obsesyjną koncentrację na „czystości” („Przyczyną główną [...] jest moje pojęcie o czystości. Celem - jest czystość"; DW VII, 230) jest wiersz Purytanizm z 1865 roku. Dominują w nim skojarzenia z czystością i drastycznym ograniczeniem zakresu wartości: „Na purytanizm, jak na rzecz obrzydłą, / Czemu? się gniewam (pytasz). Primo: wcale / Że się nie gniewam na najczystsze mydło, / Którego pianę, to jest: wartość, chwalę - / Pozwól mi tylko gęsim skreślić piórem / (Które pluskało się przez żywot cały), / Że mydło - nie jest rzeziebnym marmurem; / Dobre na bańki, nie - na ideały!” (PWsz II, 67). Pięć strof dalej znajdziemy fragment, który mógłby być komentarzem do ucieczek Singelwortha przed „nieczystą” rzeczywistością: „Ergo: uważam za istne prawidło / (W którego kole się zaklętym kręcę), / Że marmur - marmur, zaś mydło jest mydło, / Że - robić z mydła, to - umywać ręce!” (PWsz II, 68).

Tytuł wiersza nie pozostawia wątpliwości, że nie mówi on o zachowaniu higieny. Opinia na temat purytanizmu jest niesprawiedliwa w swej upraszczającej jednostronności, niemniej należała do stałych przekonań poety. Rok przed napisaniem przywołanego wiersza Norwid podzielił się podobnymi przemyśleniami z Władysławem Zamoyskim.Uwypuklił graficznie fragment wypowiedzi dotyczącej interesującego mnie zagadnienia: „,cz e mu purytanizm nawet w religi i jest he re zją???" (PWsz IX, 131). Dodał do tego jeszcze zjadliwy komentarz, potwierdzający negatywny sąd o nieadekwatności tego ruchu religijnego wobec zmieniającej się rzeczywistości, a także o jej redukującym doktrynalizmie: „Nawet w religii purytanizmu doprowadziłby zawsze albo do żydostwa, albo do archeologii, i skończyłoby się na tym, że Ko ś c i ó 1 b y ł o b y to m u z e u m sta ro ż y t n o ści!"”. Archeologia i muzeum starożytności to alegorie skostnienia. Warto dodać, że Norwid dopełnił ten fragment swojej listownej wypowiedzi dziwną z pozoru uwagą: „Nieuwerkerke byłby Papieżem!” (PWsz IX, 131). W istocie pozostał w sferze tych samych skojarzeń, łącząc „nowy kościół" i hrabiego Alfreda Émiliena de Nieuwerkerke, rzeźbiarza, kolekcjonera, wielbiciela sztuki antycznej, a od 1849 roku zachowawczego dyrektora francuskich muzeów, kilka lat później ważnej postaci w świecie politycznym Drugiego Cesarstwa Francuskiego. Norwid, jak sądzę, podkreślił w ten sposób programowe zamknięcie muzeów w bezpiecznym świecie dzieł z odległej przeszłości i propagandowe wykorzystanie takich wzorców w kształtowaniu imperialnego wyobrażenia Francji pod władaniem Napoleona III. Swoim zwyczajem poeta połączył więc estetykę z etyką, akcentując misję społeczną sztuki. 
Hrabia Nieuwerkerke nie był jednak pierwowzorem Singelwortha. Alegoria archeologii zyskała natomiast nieco inne znaczenie, kiedy narrator noweli użył jej do określenia religijnej tradycji europejskiej:

[...] improwizator Toni di Bona Grazia [...] głosił, że ulatujący podróżnik jest mężem misji, jest uprzedzicielem i zwiastunem Wielkiej Epoki nowej, która ma stać się dla ludzkości całej rodzajem puryfikacji i czymś do Revivalu amerykańskiego podobnym... Revivalu, o którym (mówiąc i szczerze, i na stronie) ani nasz stary, ukształcony i niewolniczy kontynent nie ma słusznego pojęcia, ani byłby na siłach, ażeby go u siebie spróbować i zaszczepić!... Archeologia tu raczej, lubo wstecz, ale żywo i świetnie — działa [...] (DW VII, 232).

Zestawienie negatywnie rozumianej ,puryfikacji” z pozytywną opinią na temat Revivalu - amerykańskiej odnowy religijnej, skłania do zastanowienia. Można by za Wiktorem Weintraubem uznać, że Norwid nie mógł wypowiedzieć się pochlebnie o Revivalu ${ }^{14}$. Mnie się jednak wydaje, iż opinia na ten temat jest podwójnie ironiczna: w ten sposób można czytać wypowiedź Toniego di Bona Grazia i narratorski komentarz do niej.

Improwizator, podobnie jak Singelworth, nie jest postacią jednoznaczną, jednak to jemu powierzono w tekście rolę komentatora wydarzeń. W otaczającej rzeczywistości Toni odczytuje znaki zapowiadające nieuchronne zmiany. Zapatrzenie Bona Grazii w proroczą misję aeronauty narrator jednak dezawuuje, wyrażając zadowolenie z dominacji w Europie (nie tylko w Wenecji) religijnej tradycji. Niemniej cały tekst jest rejestracją sytuacji w mieście tuż przed przełomem, którego symptomy zaczynają się uwidaczniać. Zofia Dambek-Giallelis przypomniała, że Zenon Przesmycki, w komentarzu do Pism zebranych Norwida, wśród przyczyn powstania „trylogii włoskiej”, wymieniał nostalgię za Wenecją sprzed wejścia w skład, w 1866 roku, zjednoczonych Włoch. Badaczka dodała dwie informacje ważne z mojej perspektywy: „utratę autonomii i zyskanie nowego życia w młodej wspólnocie politycznej" ${ }^{15}$. Pamiętajmy, że zarówno purytanizm, jak i genetycznie związany z nim, amerykański Revival były ruchami religijnymi o bardzo silnym wpływie na życie polityczne. Ważniejszy wydaje mi się jednak fakt użycia słowa revival w puentującym tekst zakończeniu, które mówi o religijnej odnowie.

Amerykańskie religijne Revivale miały trzy odsłony. Polski poeta z pewnościązauważył w czasie swojego pobytu skutki drugiego z nich, mógł również doświadczyć atmosfery narastającej przed trzecim, gdyż pojawił się na jego progu (początek datuje się, nieco umownie, na rok 1855) w jednym z centrów - Nowym Jorku. Pierwszy z nich bywa nazywany Evangelical Revival. Objął on angielskich

14 W. Weintraub, Norwid i Ameryka, ,Studia Norwidiana” 14: 1996, s. 18.

15 Z. DambeK-Giallelis, s. 185. 
protestantów zarówno na Wyspach, jak i w brytyjskich koloniach w Ameryce. Nazwę tę stosuje się z reguły w odniesieniu do wydarzeń w Wielkiej Brytanii, niemniej w wydanej w 1845 roku, poczytnej wówczas publikacji dotyczącej dziejów tych wydarzeń przypomniano, że jeden z kształtujących je teologów, Jonathan Edwards, mówił o „The Revival of Religion in New England in 1740 "16. Wspominam o tym, gdyż wówczas stosowano raczej nazwę „Awakening”. Kuszące jest przypuszczenie, że Norwid skorzystał jednak z nazwy Revival, by wyzyskawszy angielskie znaczenie, podkreślić, iż tekst mówi też o religijnym przełomie.

Wróćmy jeszcze do alegorii archeologii. Wenecja w noweli jest miastem, które opiera się zmianom dzięki swojej historii, obyczajom i aktualnej sytuacji. „Stojącą u bram" nowoczesność powstrzymuje bowiem także obecność okupacyjnego wojska.Wynikające z tego ograniczenie swobód jest elementem czasu przejściowego, gdyż ograniczając kontakty tradycyjnie otwartego miasta handlowego, wspiera zamianę Wenecji w „muzeum” jego przeszłości. Z drugiej strony, miasto broni własnej autonomii swoją historią. Jej ślady wpisane są w tkankę miejską, przypominają o chlubnych wydarzeniach, lecz także o przyswojonych wzorcach z innych kultur:

[...] Wenecja, nazbyt będąc oryginalną, ażeby mogła być ostatecznie ujarzmioną, pozostawała tym samym dziwnym miastem.

Miastem, w posadach swoich mającym pierwowieczną lakustralną konstrukcję na palach; potem targiem-rybaków i uskoków schronieniem; potem jeszcze miastem kramarzących z fenicka przedsiębiorców, zawiązanych nareszcie w Republikę, bynajmniej spartańską, ale owszem noszącą bisior szeroki, który leniwo wlókł się za złotym jej sandałem, nieco na azjacki lub wschodni sposób szpiczastym i w górę podkrzywionym.Miastem - które zaiste że przeżyło idyllę, dramę, nadużyło tragedii i komedii i które, jako znudzona już wszystkim wielka dama, pozostało piękne i czarowne [...] (DW VII, 223-224).

Tak postrzegana „archeologia” zbudowana jest z nakładających się warstw przeszłości - „okrytych kurzawą palimpsestów” (DW VII, 223) i „,butwiejących kart kronik Rzeczypospolitej”, przez które „dawnego życia obrazy przeświecały" (DW VII, 223). Trwanie jest jednak czasem jałowego zastoju, w którym brak „dziedziny politycznego i literackiego życia” (DW VII, 222). Toni di Bona Grazia wprawdzie jako jedyny spośród bohaterów rozumie, że nadchodzi czas zmian, jednak pełniąc funkcję miejskiego improwizatora, którego wieszczenia traktowane są zwyczajowo z pobłażliwością, jest elementem tradycyjnego porządku. Ład ten podtrzymuje konwencja, do której dostosowują się również austriaccy żołnie-

16 J. Tracy, The Great Awakening. A History of the Revival of Religion in the time of Edwards and Whitefield, Boston - New York - Philadelphia, 1845, s. iii. 
rze. Przywdziewanie masek, pozy, rytuały czynią ją grą, pozbawioną pierwotnej, głębszej treści. Konwencja zastępuje pamięć, zabytki przestają być wspomnieniem ważnych wydarzeń i stają się miejską atrakcją, „dla których jednakże podziwu się ma więcej niż żywego spółczucia człowieczego!....” (DW VII, 224). Brudu i zapachów kanałów, zastępujących w tym mieście tradycyjne ulice,stanowiących jego materialne i przenośne fundamenty, nie dostrzega się i nie czuje. Rytuał zobojętnia zarówno na samobójców, skaczących ze sławnych budowli, jak i na nieprzyjemne doznania, kanały zasłania się chwiejną konstrukcją z gondoli - popularnego środka transportu i jednego z symboli miasta:

U mostu wysokiego - u Rialto - flagi wszystkich barw, chorągwie wszystkich wieków i ludów grały wstęgami w wietrze - małe maskaradowe okręta, wyzłacane nawy z różnych epok, galery pstre herbami, czarne gondole i rozmaite statki spotykały się tak nieraz żebrami boków swoich, iż suchą nogą mogłeś przejść całą kanału szerokość, tam i napowrót. (DW VII, 233)

Bona Grazia patrzy na swoje miasto krytycznie, dostrzega jego wady, ale z rezygnacją je akceptuje, uznając za część skomplikowanego charakteru i historycznego dziedzictwa tego miejsca. Smutny, mądry błazen, pobłażliwie postrzegany przez swoich słuchaczy. Singelworth z kolei jest jednostronnie radykalny. Jego rzekomego wysokiego pochodzenia nikt nie kwestionuje, z honorami podejmowany jest przez miejskie elity, jednak nikt też nie pojmuje jego ekscentrycznych poglądów. Jest więc uważany za niegroźnego maniaka latania. Obaj z powodu nierozumienia traktowani są kpiąco, jednak to o lordzie Toni mówi: „Lecz nie należałoby właściwiej podzielić i uzasadnić mniemanie, iż powietrzny latawiec ma jedną z tych głębokich historycznych tajemnic, które się dopiero po wiekach wyjaśniają?" (DW VII, 223).

Trudno oprzeć się skojarzeniu tej jednoznacznej oceny bohatera z przekonaniem Norwida o braku zrozumienia ze strony współczesnych, połączonym z wiarą we właściwe odczytanie jego przesłania przez potomnych. Pozwolę sobie na dopisanie do tego skojarzenia kilku elementów. Jeśli uznać, że twórca obdarzył angielskiego lorda niektórymi swoimi cechami, to konserwatywną moralność Singelwortha, niejako naturalną wyniosłość, wreszcie - eskapizm można by uznać za rodzaj autokrytycyzmu czy nawet autoironii.Tak tytułowy bohater noweli, jak Norwid zachowali jednak przekonanie o misyjności własnych działań. 


\section{BIBLIOGRAFIA}

Adamiec M., Tajemnica lorda Singelworth albo metafizyka balonu, „Studia Norwidiana” 3-4: 1985-1986, s. 201-215.

Cheyne G., The English Malady or a Treatise of Nervous Diseases of all Kinds as Spleen, Vapours, Lowness of Spirits, Hypochondrical, and Hysterical Distempers, etc., London 1734.

DambeK-Giallelis Z, Tajemnice „,Tajemnicy Lorda Singelworth”, „Studia Norwidiana” 35: 2017, s. 185-198.

DĄBrowicz E., ,, Tajemnica lorda Singelworth” Cypriana Norwida - strategia publicznego mówienia, „Studia Norwidiana” 3-4: 1985-1986, s. 221-223.

GillesPIE R., Ballooning in France and Britain, 1783-1786: Aerostation and Adventurism, „Isis” 2: 1984 (75), s. 249-268. JSTOR, www.jstor.org/stable/231824, dostęp: 12.05.2020.

Grabowski M., Topografia pamięci w ,,Tajemnicy Lorda Singelworth” Norwida, „Pamiętnik Literacki" 2016 z. 4, s. 79-95.

KąCKa E., Świat wzniosłych uczuć i dobrych manier, czyli Norwidowskie prawo inwersji, „Studia Norwidiana" 38: 2020, s. 99-109.

LEERSSEEN J., Imagologia: o zastosowaniu etniczności do nadawania światu sensu, „Porównania. Czasopismo poświęcone zagadnieniom komparatystyki literackiej”, 2017, t. 21, nr 2, s. 9-29.

Lynn M.R., The Sublime Invention: Ballooning in Europe, London 2010.

Miller I., A Modern history of a Stomach, New York 2016.

Tracy J., The Great Awakening. A History of the Revival of Religion in the time of Edwards and Whitefield, Boston-New York-Philadelphia 1845.

Trojanowiczowa Z., Dambek Z. przy współudziale Czarnomorskiej J., Kalendarz życia i twórczości Cypriana Norwida, t. I: 1821-1860, Poznań 2007.

TrYbuś K., Maska lorda Singelwortha, „Studia Norwidiana” 14: 1996, s. 96-97.

TUCKer J., Voyages of Discovery on Oceans of Air: Scientific Observation and the Image of Science in an Age of 'Balloonacy', "Osiris”, vol. 11, 1996, s. 144-176. JSTOR, www.jstor. org/stable/301930, dostęp 15.08.2020.

Weintraub W., Norwid i Ameryka, „Studia Norwidiana”, 14: 1996, s. 5-19.

\section{CZYSTOŚĆ LORDA SINGELWOTHA}

\section{Streszczenie}

W artykule poddano analizie postać głównego bohatera Tajemnicy Lorda Singelworth z perspektywy XIX-wiecznej imagologii. Z tej analizy wynika, że postać została skonstruowana z rozpowszechnionych w ówczesnej Europie stereotypów na temat Brytyjczyków. Tłumaczą one dziwactwa Singelwortha: latanie balonem, obsesję czystości. Wyjaśniają również, dlaczego większość obserwatorów balonowej pasji lorda zgodnie przyjmowała zaskakujące jej wyjaśnienie - pragnienie uregulowania kłopotów gastrycznych. Uzupełnia ten zestaw charaktery- 
styczna wyniosłość, moralna motywacja działań, poczucie misji i eskapizm. Autor tekstu stawia tezę, że tak skonstruowana figura Anglika, umiejscowiona w Wenecji u progu historycznych zmian mogła być literackim autoportretem Norwida.

Słowa kluczowe: imagologia; aeronautyka; English malady; American Revival.

\section{THE CLEANLINESS OF LORD SINGELWORTH}

\section{Summary}

The paper presents an analysis of the protagonist of Tajemnica Lorda Singelworth [Lord Singleworth's Secret] in terms of the $19^{\text {th }}$ century imagology. The analysis shows that the character was created on the basis of stereotypes of the British that were popular in Europe at that time. They account for Singleworth's oddities such as flying in a hot air balloon or his obsession with cleanliness. They also explain why the majority of those who observed Lord's balloon passion unanimously accepted its surprising justification - the need to deal with his gastric problems. This is then complemented by the peculiar arrogance, moral motivation for action, sense of mission and escapism. The author of the paper assumes that the character of an Englishman developed in such a way and placed in Venice on the threshold of historical changes might be a literary self-portrait of Norwid.

Key words: imagology; aeronautics; English malady; American Revival.

DARIUSz PNIEwsKi - dr hab., prof. UMK, pracuje na Wydziale Humanistycznym Uniwersytetu Mikołaja Kopernika w Toruniu, autor monografii: Między obrazem i słowem. Studia o pogladach estetycznych i twórczości literackiej Norwida, wydajnej przez Wydawnictwo KUL w 2005 i Przywłaszczenie i strata. Romantyczne transfiguracje Jezusa", opublikowanej w Wydawnictwie Naukowym UMK w 2014. Zajmuje się tekstami literackimi i myślą estetyczną Cypriana Norwida, literaturą, malarstwem i estetyką europejskiego romantyzmu (brytyjskiego, francuskiego, niemieckiego, rosyjskiego i polskiego), a także artystycznymi wykorzystaniami figury Jezusa w kontekstach pozareligijnych (zwłaszcza społecznych i politycznych).Adres email: dariusz.pniewski@umk.pl 